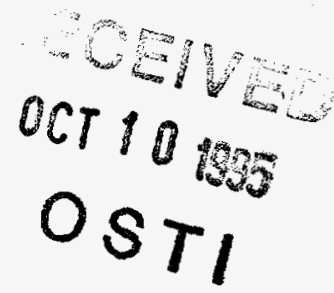

REV. 0

\title{
Comment And Response DOCUMENT FOR THE Ground Water Protection Strategy FOR THE URANIUM MILL TAILINGS Site AT GREen RIVER, UTAH
}

\author{
September 1995
}

\section{DISCLAIMER}

\begin{abstract}
This report was prepared as an account of work sponsored by an agency of the United States Government. Neither the United States Government nor any agency thereof, nor any of their employees, makes any warranty, express or implied, or assumes any legal liability or responsibility for the accuracy, completeness, or usefulness of any information, apparatus, product, or process disclosed, or represents that its use would not infringe privately owned rights. Reference herein to any specific commercial product, process, or service by trade name, trademark, manufacturer, or otherwise does not necessarily constitute or imply its endorsement, recommendation, or favoring by the United States Government or any agency thereof. The views and opinions of authors expressed herein do not necessarily state or reflect those of the United States Government or any agency thereof.
\end{abstract}
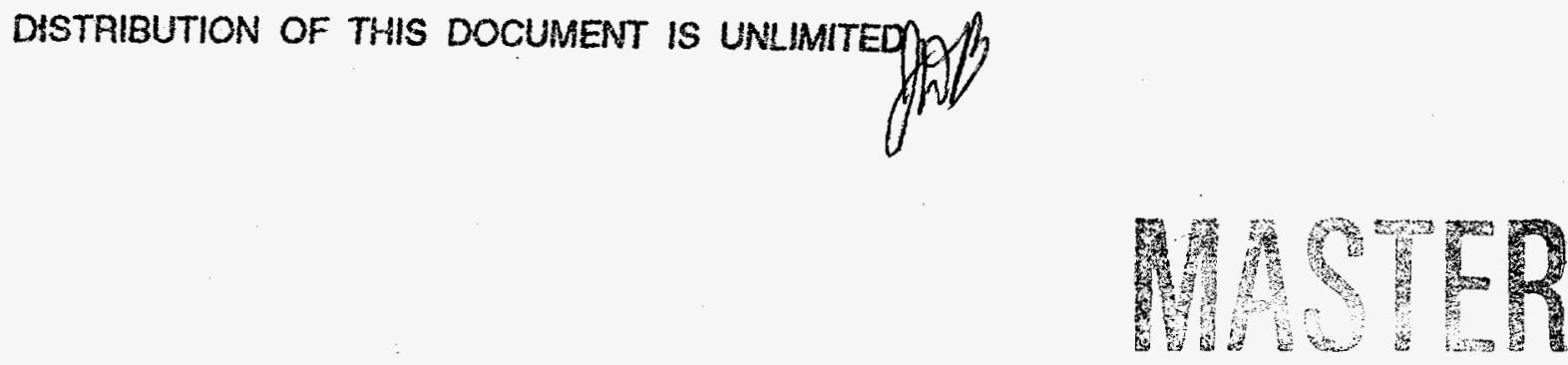


\section{DISCLAIMER}

Portions of this document may be illegible in electronic image products. Images are produced from the best available original document. 
REV. 0

COMMENT AND RESPONSE DOCUMENT FOR THE GROUND WATER PROTECTION STRATEGY FOR THE URANIUM MILL TAILINGS SITE AT GREEN RIVER, UTAH

September 1995

Prepared for

U.S. Department of Energy

Environmental Restoration Division UMTRA Project Team

Albuquerque, New Mexico

Prepared by Jacobs Engineering Group Inc. Albuquerque, New Mexico 


\author{
Comment and Response Document for the \\ Ground Water Protection Strategy for the \\ Uranium Mill Tailings Site at Green River, Utah \\ July 1995 \\ (DOE/AL/62350-194, Rev. 0)
}

\title{
1.0 INTRODUCTION
}

The U.S. Department of Energy (DOE) responses to comments from both the U.S. Nuclear Regulatory Commission (NRC) and the state of Utah are provided in this document. A revised copy of the Proposed Ground Water Protection Strategy for the Uranium Mill Tailings Site at Green River, Utah (DOE/AL/62350-169, Rev. 2, July 1995), incorporating changes based on the comments, is attached for regulatory review and concurrence.

The Proposed Ground Water Protection Strategy for the Uranium Mill Tailings Site at Green River, Utah, presents the proposed (modified) ground water protection strategy for the disposal cell at the Green River disposal site for compliance with Subpart A of 40 CFR Part 192. Before the disposal cell was constructed, site characterization was conducted at the Green River Uranium Mill Tailings Remedial Action (UMTRA) Project site to determine an acceptable compliance strategy. Results of the investigation are reported in detail in the final remedial action plan (RAP) (DOE, 1991a); additional information is presented below. The NRC and the state of Utah have accepted the final RAP (see signature page in the RAP dated 22 January 1990). The changes in this document relate only to a modification of the compliance strategy for ground water protection. The proposed compliance strategy in the vicinity of the Green River disposal cell is application of supplemental standards (40 CFR \$192.22(a); 60 FR 2854 (1995)) based on limited use ground water in the uppermost aquifer that is associated with widespread natural ambient contamination (40 CFR $\$ 192.11(e)$; 60 FR 2854 (1995)). This compliance strategy does not require ground water monitoring according to the final EPA standards (60 FR 2854 (1995)), but the DOE currently monitors ground water as a "best management practice." Therefore specific numerical concentration limits have not been specified and designated "point of compliance" wells are not being monitored. This document will be included in Modification 2 to the final RAP of March 1991 (DOE, 1991a) and will replace the existing Appendix $E$ of the RAP.

References to page numbers in the comments refer to those in the document reviewed (Rev. 1, November 1994), and page numbers in the responses refer to those in the revised document (Rev. 2, July 1995).

\subsection{NRC COMMENTS AND RESPONSES}

The following comments were received from the NRC in a letter dated 17 January 1995. DOE responses are provided below. 


\section{COMMENT: 1}

As a result of its initial review, the NRC staff has identified a need for additional information. This request, which addresses information needs relative to DOE's position on widespread, ambient contamination at the Green River site, is discussed in detail in the enclosure.

\section{Issue}

Well monitoring data provided in the proposed groundwater protection strategy are not sufficient for NRC staff to make an independent determination that widespread, ambient contamination of the uppermost aquifer (i.e., the Cedar Mountain Formation) exists at the Green River UMTRA Project site.

\section{Basis}

- DOE states (p. 3-8) that data obtained from the following suite of wells were used in the determination of background water quality: 5 wells upgradient of the disposal site, 13 wells downgradient or crossgradient of the disposal site, 3 wells upgradient of the former processing site, and 5 wells in the Buckhorn Member (which lies below the Cedar Mountain Formation).

- DOE states (p. 3-8) that, "The quality of the water found in crossgradient and downgradient wells is not affected by the presence of the disposal cell, and no baseline wells are close enough to the former processing site area to be impacted by the contaminated, unconfined alluvial aquifer water underlying the former processing site area." Detailed monitoring well data to support these statements are not presented in the strategy.

- Summarized ranges of concentration levels for selenium and other constituents are provided for wells identified as upgradient and cross- or downgradient of the disposal site (Table 3.4, p. 3-13). However, the wells used in the analysis are not identified.

- As shown in Table 3.4 (p. 3-13), the observed concentrations for selenium in the uppermost aquifer are within the maximum concentration limit $(\mathrm{MCL})$ for selenium. DOE states, however, that selenium levels in the uppermost aquifer are "typically elevated" above the MCL (p. 3-11).

- The NRC staff considers that additional well monitoring data will need to be provided in support of DOE's contention that widespread, ambient contamination of the Cedar Mountain Formation exists at the Green River site. 


\section{Information Request}

DOE should provide all background water quality data by well, for multiple well locations positioned upgradient of the disposal site and cross- and downgradient of the disposal site. These data should cover a period of no less than 3 consecutive calendar years (with the final year in the series being 1994), and cover all sampling periods within each year.

\section{RESPONSE:}

Pages 2-1 and 3-8 By: R. Heydenburg Date: 25 April 1995

In response to the first issue, the DOE has revised portions of the document and will provide relevant well monitoring data to the NRC.

- Several sections have been revised to clarify the discussions of hydrogeologic and geochemical conditions at the Green River site (Section 2.1.2 on page 2-1), and to assess ground water quality at the disposal site (part of Section 3.2.1 on page 3-8). A revised monitor well location map, cross sections, and potentiometric surface map for the uppermost aquifer have also been included (Figures 2.1 through 2.4).

- Water quality data by monitor well location are provided for the period from June 1986 through July 1994 in Table SI.4 in the supplemental information section to this document. Background ground water quality in the Cedar Mountain Formation in the vicinity of the Green River disposal site was determined by analyzing ground water samples collected from representative monitor wells in off-site areas not affected by uranium processing activities. These were upgradient disposal-site monitor wells GRN-01-0178 and -0180; monitor wells GRN-01-0585, -0806, and -0811 in the unnamed member (uppermost aquifer); and monitor wells GRN-01-0582, -0586, -0587, -0588, $0817,-0818$, and -0819 in the Buckhorn Member. Water quality data for all other disposal-site monitor wells completed in the uppermost aquifer (GRN-010171 through -0176, and -0813 [downgradient]; GRN-01-0177 and -0179 [upgradient]) were not used in the evaluation of background ground water quality, but are included in the supplemental information section of this document (Table SI.4). Other monitor wells at the site are not included because ground water quality data indicate they are in areas impacted by uranium processing activities. Monitor wells completed in the alluvium were not included because they are not relevant to the evaluation of ground water quality for the disposal cell compliance strategy.

- Monitor well information (Table SI.1), ground water elevations (Table SI.2), and water quality sampling history (1986 through 1994) (Table SI.3) are also included in the supplemental information section of this document. 


\section{COMMENT: 2}

The proposed strategy does not discuss provisions for informing the local public and EPA of the proposed application of supplemental standards, in accordance with 40 CFR Part 192.22(c). The proposed strategy should incorporate appropriate discussion to meet this requirement.

\section{RESPONSE}

Page $\quad 3-4$

By: R. Heydenburg

Date: 25 April 1995

This issue has been addressed by a discussion of the DOE's intention to meet this requirement, inserted into Section 3.1 on page 3-1. 


\subsection{STATE OF UTAH COMMENTS AND RESPONSES}

Comments were received from the State of Utah in a letter dated 25 May 1995. DOE responses are provided below.

\section{COMMENT: 1}

Confirmation of Adequate Monitoring Well Network - including a fracture/joint survey of nearby bedrock outcrops to evaluate the possibility of any preferential flow directions via fractures in the Cedar Mountain Formation. An assessment should then follow to determine if the current monitoring well network is adequate in terms of well spacing, construction, and location to monitor any potential preferred ground water flow direction(s).

\section{RESPONSE}

Page NA

Date: 13 June 1995

The fracture density at the Green River site has been described previously as moderate to intense (DOE, 1991). A closely spaced disposal-site monitor-well network (150 to $200 \mathrm{ft}$ [46 to $61 \mathrm{~m}$ ] apart) was installed proximate to the disposal cell at the site. Analyses were performed to evaluate the ground water level response from pumping well (GRN-01-0173) in relation to the fractures. The analyses are described in a memorandum dated 17 August 1995. The results of the evaluation are summarized here.

Evaluation of boring logs, aerial photographs, ground water level fluctuations, and aquifer test data show that the monitor wells intercept a similar interconnected fractured porous media and that this hydrogeologic unit likely extends beneath the cell. Furthermore, the ground water flows toward the northwest, so the wells are downgradient from the disposal cell. Finally, though fractures are present, they do not appear to cause any preferred direction of flow. This supports the conclusion that the existing wells will adequately monitor ground water quality immediately downgradient of the disposal cell.

This evaluation considered soil boring logs from wells IGRN-01-0171, -0172, $-0173,-0174,-0175$, and -0176 . Lithology shows minor variation in the field description of the unnamed member of the Cedar Mountain Formation. Siltstones and sandstones dominate with lesser claystone and mudstone. Geologic cross sections with some interpretation of the extent of the sandstone show the interconnection of the uppermost transmissive hydrogeologic unit. 
A rose diagram showing the dominant direction of fractures was developed using aerial photographs. The dominant trend in fractures is from $\mathrm{N}^{\circ} 0^{\circ} \mathrm{W}$ to $\mathrm{N} 80^{\circ} \mathrm{W}$. Field observations were consistent with this trend and reported a fracture spacing of 2 to $5 \mathrm{ft}(0.6$ to $1.5 \mathrm{~m})$.

A hydrograph of monitor wells shows their consistent response to natural fluctuations. Ground water levels were measured twice per year from 1991 to 1995. The consistency observed supports the conclusion that none of the wells will respond independently of the others.

The aquifer test conducted in October 1993 was designed to evaluate the sustainable vield of the sandstone unit. The water level response to pumping is consistent though some variability exists. Of the analysis methods applied, a double porosity model of a fissured aquifer (Moench, 1984), fits the data most favorably. The results show no apparent trend between the direction of the monitor wells and the estimated hydraulic conductivity. UMTRA TAC Calc. No. GRN-0895140300 describes the aquifer test analysis. 
COMMENT: 2

Evaluation of Hydrogeochemical Conditions - at the facility to assess groundwater flow system characteristics, aquifer inter-relationships, and water quality conditions. This information should be valuable in the confirmation of the adequacy of the monitoring well network.

\section{RESPONSE}

Page NA

By: E. Larsen/D. Erskine

Date: 13 June 1995

The current level of characterization at the Green River site is sufficient to address whether the remedial action will comply with the surface remediation phase (Subpart A) of the proposed EPA ground water protection standards (see Section 2.1.2).

Current knowledge of background conditions in the unnamed member of the Cedar Mountain Formation comes from analyses of ground water in five monitor wells (178, $180,585,806$, and 811 ), believed to be upgradient, crossgradient, or far enough downgradient to be unaffected by processing-related contamination. All analyses show a sodium sulfate water, however, based on TDS content, with two distinct groups. One group (monitor wells 178,806 , and 811 ) have a TDS content near $2400 \mathrm{mg} / \mathrm{L}$. The other group (monitor wells 180 and 585) have a TDS content near $6000 \mathrm{mg} / \mathrm{L}$.

The lack of obvious upgradient recharge to the Cedar Mountain Formation raises questions regarding the source of ground water at the site. The velocity of ground water at the site is poorly known, but if it were on the slow end of the observed range, recharge could be derived primarily from precipitation directly in the area of the site. Given enough time, differences in ground water chemistry might be due to variable evaporation from the water table. However, this scenario is unlikely since evaporation would enhance chloride over sulfate in the high TDS water and this condition is not observed in the chemical analyses. Further, if evaporation were the cause of chemical differences, we would expect to find a range of TDS rather than two distinct groups.

Another possible source of recharge is leakage from semiconfined units that underlie the Cedar Mountain Formation. Ground water from monitor wells completed in the Buckhorn Conglomerate (directly underlying the unnamed member of the Cedar Mountain Formation at the site) is of a sodium-sulfate type and it commonly has a TDS content near $2400 \mathrm{mg} / \mathrm{L}$. This suggests that the source for the low TDS ground water in the unnamed member could be the Buckhorn Conglomerate. Ground water in all monitor wells completed in the Buckhorn is of a low TDS type. Therefore, this unit is not the source of high TDS ground water observed in the unnamed member. No DOE monitor wells are completed in the Morrison Formation (underlying the 
Buckhorn at the site; however, a preliminary literature search indicates this unit produces ground water in the 6000 TDS range in the Green River area (USGS, 1982) and this may be the source of high TDS water in the unnamed member.

Additional investigations will be conducted as necessary to determine the appropriate ground water cleanup strategy for the Green River site. These investigations may be implemented during a later phase of the ground water remediation program and if so, they will be guided by the preliminary site characterization work described in the response to Comment 1. 


\section{COMMENT: 3}

Expansion of Ground Water Monitoring Parameters - to include several additional contaminants beyond the nitrate, sulfate, and uranium proposed in the November 8 , 1994 Proposal. These contaminants would include others known to exist in the tailings, for which State based Ground Water Quality Standards exist or could be derived. Details regarding the final number and identity of these contaminants would be subject to further discussion and negotiation.

\section{RESPONSE}

Pages 3-1 and 3-2

By: E. Larsen

Date: 13 June 1995

Initially, ground water samples collected from Green River monitor wells were analyzed for a wide range of hazardous constituents. However, the current list of parameters reflects only those constituents that are possibly related to uranium milling activities and of relevance to this investigation.

Under the current ground water monitoring program at the Green River site, the disposal-site monitor well network is sampled semiannually. The analyte list for these monitor wells includes the following parameters:

Hazardous constituents: arsenic, cadmium, chromium, lead, molybdenum, nickel, nitrate, selenium, uranium, vanadium, radium-226, radium-228, and gross alpha.

Major cations and anions: calcium, manganese, sodium, potassium, chloride, sulfate, and phosphate.

Geochemical indicator parameters: aluminum, iron, magnesium, zinc, ammonium, and total and dissolved solids.

Water quality data by monitor well location are provided for the period from June 1986 through July 1994 in Table SI.4, which is included in the supplemental information section of this document. The range of hazardous constituent concentrations for monitor wells sampled between 1986 and 1995 will be provided in the Green River water sampling and analysis plan (WSAP), which currently is being revised.

Section 3.3.1 has been revised to clarify the discussion about the criteria used to identify constituents that will be used to monitor the potential migration of tailingsrelated contamination into ground water beneath the disposal cell. The current list of constituents (nitrate, sulfate, and uranium) has been modified to include TDS. Numerical concentration limits for each constituent were established separately for each disposal site monitor well downgradient from the disposal cell. These limits 
(now termed supplemental standard limits) represent reasonable and protective upper limits for future ground water concentrations based on the available data, but there is no certainty they will be applicable over time. If the supplemental standard limits are exceeded during the course of monitoring, the analyte list will be expanded to include copper. The statistical basis used to develop the supplemental standard limits are discussed in detail in the response to Comment 4. 


\section{COMMENT: 4}

Establishment of Groundwater Quality Action Limits - to be used to assess performance of the engineered containment to control the contaminants in the tailings. These concentration limits could be derived by a number of methods, subject to further discussion and State approval.

\section{RESPONSE}

Page $3-1$

By: K. Smith

Date: 13 June 1995

Although it is true that concentration limits could be derived by a number of methods, any method must account for these factors:

- Ground water in the vicinity of the site is associated with preexisting contamination from uranium milling activities that took place on the site.

Therefore, concentrations in disposal site monitor wells downgradient of the cell generally are above background levels.

- Contaminant levels vary somewhat unpredictably over short distances on the site.

- Effective evaluation of potential impacts to ground water by seepage from the disposal cell must take into account the preexisting contamination.

Consideration of these factors reduces the number of possible approaches for setting concentration limits down to two. The first uses statistical methods to set limits. Limits tied to actual numerical data from monitor wells collected after the disposal cell was completed, but before any transient effects from cell construction become measurable, serve the valuable purpose of establishing a baseline against which future changes in ground water can be judged.

The second method assigns a concentration limit higher than baseline but tied to a regulatory standard or a numerical standard protective of a beneficial use of the ground water. The proposed concentration limits for the Green River disposal cell represent a combination of these two methods. The limit is set at the upper end of baseline unless this level is below the UMTRA Project MCL, in which case the limit is set equal to the MCL. UMTRA Project MCLs are available for uranium and nitrate, but not for sulfate and TDS. Disposal cell baseline concentrations of sulfate are above the federal secondary drinking water standard $(250 \mathrm{mg} / \mathrm{L})$, the proposed EPA primary drinking water standard $(500 \mathrm{mg} / \mathrm{L})$, and concentrations deemed protective of livestock ( $1000 \mathrm{mg} / \mathrm{L})$. Therefore, concentration limits for sulfate and TDS are set on baseline conditions. 
Section 3.0 of the Ground Water Protection Strategy has been revised to reflect the current state of knowledge concerning the preexisting contamination at the disposal site and to justify the use of baseline limits as supplemental standard limits for longterm monitoring at the disposal site. However, the final numerical limits and other details concerning long-term monitoring at the disposal site will be presented in the site LTSP. The 1994 LTSP will be revised in the near future to incorporate revisions to the RAP. At that time, the following text and table will be proposed for inclusion in the revised document.

Ground water in the vicinity of the disposal cell was impacted by uranium processing activities that took place on the site (DOE, 1994b), and concentrations of the selected monitoring constituents were above ambient background levels prior to construction of the disposal cell. The preexisting concentration levels in ground water downgradient of the disposal cell represent the baseline against which future disposal cell ground water monitoring data should be compared.

Chemical analysis data from filtered ground water samples collected at least twice each year between August 1990 and June 1994 were used to evaluate natural variations in constituent concentrations over time in ground water accessed by wells downgradient of the disposal cell (GRN-01-0171 through -0176 and -0813). The time period allowed data to be incorporated from at least 10 sampling rounds. Table 1 summarizes data from these sampling rounds.

Because constituent levels vary over short distances in the vicinity of the disposal cell, baseline ranges were established separately for each monitor well and constituent. A reasonable upper limit for the concentration of each constituent in ground water was calculated using the tolerance interval approach on pages 49 to 54 of EPA (1992). The selected limit provides 95 percent confidence that at least 95 percent of all future measurements will lie below the upper limit of the tolerance interval, provided contamination levels do not trend upward in the future.

Estimating a tolerance interval from small numbers of data requires fitting the available water quality data into a theoretical probability model and then extrapolating beyond the data into the right tail of that model. The validity of the estimate is dependent upon the choice of an appropriate theoretical model for the data.

Following EPA recommendations on page 2 of the addendum to interim final guidance (EPA, 1992), the lognormal probability distribution was evaluated as a first choice for describing the water quality data of individual wells.

The fit of the lognormal distribution to the 10 to 12 data points available for a well was evaluated using the probability plot correlation coefficient method described on page 13 of the guidance document (EPA, 1992). A total of 28 goodness-of-fit tests were performed, including 7 wells and 4 constituents. To minimize the likelihood of obtaining at least one false-positive result among the 28 tests, the 0.01 level of significance was used for each individual test for lognormality. The lognormal fit to the data was determined adequate for all wells and constituents. 
Table 1 Summary of ground water quality and proposed supplemental standard limits for disposal cell monitor wells, Green River, Utah, site

\begin{tabular}{|c|c|c|c|c|c|}
\hline $\begin{array}{c}\text { Monitor } \\
\text { well } \\
\text { (GRN-01) }\end{array}$ & $\begin{array}{c}\text { Number of } \\
\text { samples }\end{array}$ & \multicolumn{2}{|c|}{ Auqust 1990 - June 1994} & $\begin{array}{c}\text { Tolerance } \\
\text { limit }\end{array}$ & $\begin{array}{c}\text { Proposed } \\
\text { supplemental } \\
\text { standard limit }\end{array}$ \\
\hline \multicolumn{6}{|c|}{ Nitrate $(\mathrm{MCL}=44 \mathrm{mg} / \mathrm{L})^{\circ}$} \\
\hline-0171 & 10 & $1.2-6.6$ & 3.6 & 18 & 44 \\
\hline-0172 & 10 & $32-108$ & 57 & 153 & 153 \\
\hline-0173 & 10 & $<1.0-5.3$ & 1.7 & 10 & 44 \\
\hline-0174 & 10 & $<1.0-4.1$ & 1.6 & 8 & 44 \\
\hline-0175 & 10 & $<1.0-3.8$ & 1.4 & 6 & 44 \\
\hline-0176 & 10 & $120-293$ & 218 & 535 & 535 \\
\hline-0813 & 11 & $<1.0-9.3$ & 3.5 & 44 & 44 \\
\hline \multicolumn{6}{|c|}{ Sulfate $(M C L=250 \mathrm{mg} / \mathrm{L})^{b}$} \\
\hline-0171 & 10 & $2180-3210$ & 2780 & 3740 & 3740 \\
\hline-0172 & 10 & $3640-4760$ & 4350 & 5420 & 5420 \\
\hline-0173 & 10 & $2820-3740$ & 3420 & 4310 & 4310 \\
\hline-0174 & 10 & $2300-3450$ & 3180 & 4440 & 4440 \\
\hline-0175 & 10 & $3340-3660$ & 3570 & 3840 & 3840 \\
\hline-0176 & 10 & $3440-4300$ & 3990 & 4830 & 4830 \\
\hline-0813 & 12 & $3540-4300$ & 3970 & 4680 & 4680 \\
\hline \multicolumn{6}{|c|}{ TDS $(\mathrm{MCL}=500 \mathrm{mg} / \mathrm{L})^{\mathrm{b}}$} \\
\hline-0171 & 10 & $4850-5810$ & 5220 & 6150 & 6150 \\
\hline-0172 & 10 & $6900-8010$ & 7390 & 8410 & 8410 \\
\hline-0173 & 10 & $5900-6320$ & 6160 & 6510 & 6510 \\
\hline-0174 & 10 & $5600-5850$ & 5850 & 6270 & 6270 \\
\hline-0175 & 9 & $6030-6420$ & 6230 & 6690 & 6690 \\
\hline-0176 & 10 & $6870-10400$ & 7710 & 10,920 & 10,920 \\
\hline-0813 & 12 & $6680-6890$ & 6780 & 6960 & 6960 \\
\hline \multicolumn{6}{|c|}{ Uranium (MCL $=0.044 \mathrm{mg} / \mathrm{L})^{\circ}$} \\
\hline-0171 & 10 & $0.002-0.014$ & 0.005 & 0.022 & 0.044 \\
\hline-0172 & 10 & $0.001-0.058$ & 0.028 & 0.079 & 0.679 \\
\hline-0173 & 10 & $<0.001-0.005$ & 0.002 & 0.014 & 0.044 \\
\hline-0174 & 10 & $<0.001-0.010$ & 0.002 & 0.011 & 0.044 \\
\hline-0175 & 10 & $<0.001-0.022$ & 0.008 & 0.138 & 0.138 \\
\hline-0176 & 10 & $0.038-0.074$ & 0.059 & 0.117 & 0.117 \\
\hline-0813 & 12 & $0.034-0.060$ & 0.050 & 0.074 & 0.074 \\
\hline
\end{tabular}

a'The MCL for nitrate is $10 \mathrm{mg} / \mathrm{L}$ as nitrogen, which equals $44 \mathrm{mg} / \mathrm{L}$ as nitrate.

bederal Secondary Drinking Water Standard (40 CFR Part 143).

'The MCL for uranium is $30 \mathrm{pCi} / \mathrm{L}$, which is equivalent to $0.044 \mathrm{mg} / \mathrm{L}$, assuming secular equilibrium between major isotopes.

$\mathrm{mg} / \mathrm{L}$ - milligrams per liter. 
Increases over time in concentrations of both TDS and sulfate in well 171 and TDS in well 175 are observable from the 1990 to 1994 monitor well data. Although the upward trends are statistically significant, the estimated rates of increase in concentration levels are relatively small compared to existing levels. The TDS concentrations measured in filtered water samples from well 171 are estimated to have increased by less than 4 percent per year from $4900 \mathrm{mg} / \mathrm{L}$ in mid-1990 to 5600 $\mathrm{mg} / \mathrm{L}$ by mid-1994. Sulfate, a significant component of TDS, shows a corresponding rise from approximately 2500 to $3100 \mathrm{mg} / \mathrm{L}$ during the same sampling period. TDS concentrations measured in ground water from well 175 are estimated to have increased from 6000 to $6400 \mathrm{mg} / \mathrm{L}$ during the same period, which represents an annual average increase of less than 2 percent.

For cases with significant trends, an alternative method was evaluated for setting an upper limit on future concentrations. The method involves estimating a linear time trend through the data, and then calculating a tolerance limit for the 95th percentile of the concentration distribution as of the most recent sampling date used in the assessment (June 1994). The resulting tolerance limit for each case was approximately equal to the tolerance limit for that case calculated under the assumption of a time-stationary, lognormal probability model. Therefore, to ensure a consistent approach, the upper tolerance limits based on lognormal distributions for all seven wells and four monitored constituents are presented in Table 1. Calculations used to establish these tolerance limits are provided in a calculation set (GRN-08-95-14-11-00).

The proposed supplemental standards concentration limits for uranium and nitrate are set for each well at the upper tolerance limit or the UMTRA Project maximum concentration limit (MCL), whichever is greater. Because MCLs have not been established for sulfate and TDS, the proposed supplemental standards limits are established solely on the basis of the upper tolerance limits.

Table 1 presents the proposed supplemental standards limits for ground water protection at the Green River disposal site.

A relatively short time window was available to establish baseline ground water conditions directly downgradient of the disposal cell after completion of the cell but before any transient effects from cell construction might become measurable. Ground water conditions are dynamic and may be affected by events that take place on the scale of years or decades. The concentration limits established for disposalsite monitor wells downgradient from the disposal cell at the Green River site represent reasonable and protective upper limits for future ground water concentrations based on the available data, but there is no certainty that these limits will remain applicable over decades of monitoring at the site. 


\section{COMMENT: 5}

Determination of Statistical Methodology - to be applied to ground water quality data that will be collected from the groundwater monitoring wells. Reference made in the November 8, 1994 Proposal to the EPA RCRA ground water statistical guidance ("Statistical Analysis of Ground-Water Monitoring Data at RCRA Facilities - Interim Final Guidance, EPA/530-SW-89-026) is appropriate, however, an elaboration is needed in order to select the most appropriate methods available for fracture hydrology groundwater flow systems.

\section{RESPONSE}

Page NA

By: K. Smith

Date: 13 June 1995

As discussed in response to Comment 4 , concentration limits for monitored constituents will be set well-by-well because preexisting contamination levels are locally variable between wells. Background concentrations cannot be used in setting these limits because concentrations downgradient of the disposal cell exceed background levels as a result of processing activities at the site.

The method employed to set concentration limits will be valid when applied to fracture ground water flow systems, because the limits reflect the local concentrations in ground water at each monitor well. 


\section{COMMENT: 6}

Frequency of Groundwater Monitoring - including a justification from the DOE for the proposed annual sampling frequency. Such an assessment would require an evaluation of on-site ground water flow velocity and the needs of the statistical methodology to be employed.

\section{RESPONSE}

Page NA

By: E. Larsen

Date: 13 June 1995

Section 3.3.3 contains a detailed description of the sampling frequency for the Green River site. The description includes a plan to evaluate trends in contaminant concentrations and transport times for hazardous constituents. 


\section{COMMENT: 7}

Reporting of Groundwater Quality Results to State - a schedule for providing groundwater quality results to the State of Utah and notification in the event that a Groundwater Quality Action Limit is exceeded.

\section{RESPONSE}

Page NA

By: E. Larsen

Date: 13 June 1995

Ground water quality results are currently submitted to the state of Utah by the DOE. A schedule for providing future ground water quality results to the state of Utah will be addressed in a future revision of the LTSP for the Green River site. 
COMMENT: 8

Corrective Action - including an outline of the events that will be followed by DOE to confirm any excess groundwater quality data, to resolve such problems, and solicit State approval in the event that groundwater quality action limits are exceeded. The risk assessment mentioned in Section 5.4 of the September, 1992 Long-Term Surveillance and Maintenance Plan (DOE document UMTRA-DOE/AL-350206.0000, pp. 5-21 and 22) is one of several acceptable approaches that may be available.

\section{RESPONSE}

Page NA

By: E. Larsen

Date: 13 June 1995

Guidance regarding the exceedance of supplemental standard limits will be included in a future revision of the LTSP for the Green River site. 


\section{REFERENCES}

EPA (U.S. Environmental Protection Agencyl, 1992. Addendum to Interim Final Guidance, Statistical Analysis of Ground-Water Monitoring Data at RCRA Facilities, Office of Solid Waste Management Division, U.S. Environmental Protection Agency, Washington, D.C.

USGS (U.S. Geological Survey), 1982. Regional Hydrology of the Green River-Moab Area, Northwestern Paradox Basin, Utah, USGS Open File Report 82-107, prepared in cooperation with the U.S. Department of Energy. 